\title{
THE MASSACHUSETTS PROPOSITION FOR AN EMPLOYERS' COMPENSATION ACT.
}

A report made to the Massachusetts Legislature in January, 1904, by a "Committee on the Relations between Employer and Employee" brings before the lawyers and legislators of the United States, as well as before those of Massachusetts, for consideration the question what principles now underlie, and what should underlie, the liability of the employer to his employee for injuries received in the course of the employment.

The committee in question consisted of five men, of whom the chairman was the eminent statistician and economist, President Carroll D. Wright, and their report was unanimous as to the matter referred to in this paper. As an appendix, No. ro, to their report, there is given a valuable report by A. Maurice Low as to the operation of the English Workmen's Compensation Act, passed in 1897, and extended to agricultural laborers in 1900 .

This English act, which is proposed for adoption, with some modifications, in Massachusetts, rests upon a wholly different theory of the employer's liability to his workmen from that which now prevails in American law.

It would be difficult to state in any brief form, or with any confidence of framing a formula with which all, or even a great majority, of the American cases would be reconcilable, the theoretical basis of the existing American law.

Doubtless the original basis of the employer's liability to his employee was the same as that to the general public; to wit, the obligation to exercise due care, and the consequent liability for failure to do so.

But in the famous case of Farwell v. Boston and Worcester Railroad Company, 4 Metc. (Mass.) 49, the master's liability for the negligence of a servant acting in the course of his employment was held to have no existence if the injured man was a fellow-servant of the one whose negligence had caused the injury, because of the implied contract of the injured servant, in entering the employ, "to take upon himself the natural and 
implied risks and perils incident to the performance of such services," among which is the risk of the negligence of a fellow-servant.

One can imagine the amazement of Chief-Justice Shaw if he could have seen in a vision the vast body of case law, with its wilderness of corollaries and distinctions, its frequent coniradictions between the conclusions of the courts of different states, of different courts of the same state, and even between the decisions of the same court at different times,* which has followed his opinion in the Farwell case.

The Superior-Servant exception, the Different-Department exception, and the Vice-Principal exception, the last phrase itself being used by different courts with very different meanings, have successively been defined, doubted and denied, in the effort to do justice and at the same time follow the precedents.

The present result seems to be that the plaintiff must overcome a double line of defenses; if negligence can be imputed to him, the defense of contributory negligence, belonging to the law of tort, will defeat his action; if there is no contributory negligence, he may be defeated by any one of a series of imaginary agreements which are imputed to him by law, but of which he was himself quite unconscious.

The question whether, by the same act and as to the same risk, he is exposed to the double and alternative defense of contributory negligence and of assumption of the risk has lately had a most interesting discussion in the United States Circuit Court of Appeals of the Eighth Circuit.

In Southern Pacific R. Co. v. Yeargin, rog Fed. 436, 48 C. C. A. 497, (1901), Judges Thayer and Caldwell held that if a servant made use of machinery in which there were patent and obvious defects, the danger of which was not, however, so great that a man of ordinary prudence would not commonly incur the risk, his consent to use the machinery constituted no defense to an action for a resulting injury, the question being purely one of contributory negligence. Judge Sanborn dissented, holding that contributory negligence was one defense, resting in the law of tort, and that the asumption of the risk was another and wholly independent defense, resting

* Witness, most notably, the Ross case, decided by the Supreme Court of the United States in 1884 , I12 U. S. 377 , in which the Superior-Servant rule was adopted, but repudiated by the same court in the Conroy case fifteen years later, 175 U.S. 323; a reversal which has of course involved a like change of decision in all the inferior Federal courts. 
in implied contract, and that consequently, if the servant's use of the defective machinery was admitted, there was no question of fact to send to the jury.

Two years later, the same question came before the same court in. a suit by a girl for injuries received from the cogs of a rope-weaving machine, which the employer had left unprotected in violation of a statute; but as Judge VanDeventer was now sitting instead of Caldwell, and voted with San̈born instead of with Thayer, the former case was overruled, and the dissenting opinion therein declared to be the law.*

In the elaborate and somewhat heated discussion in this latter case, I think many readers will regard the opinion of Judge Thayer as more convincing in its reasoning, while they may admit that that of Judge Sanborn is supported by the greater weight of precedent.

It will evidently deeply interest the attorneys for the plaintiff in the next similar case before this court to learn what third judge is to sit with Thayer and Sanborn.

The fellow-servant rule, of which Sir Frederick Pollock says (Pollock on Torts, p. 84), "It is a topic far from clear in principle," is asserted as a defense in a very great proportion of the cases between employer and employee; and the uncertainty attaching to the whole law of the employer's liability is particularly unfortunate "in a matter of general public importance and affecting large classes of persons who are neither learned in the law or well able to procure learned advice" (Pollock on Torts. p. 90), and who, consequently, often fall into the hands of "ambulance-chasers" and other inferior lawyers. In hundreds of cases the injuries received by workmen are such as to entirely or considerably incapacitate them from supporting themselves and their families, and the inability to obtain a speedy and certain determination of their rights must often entail a condition of helpless suffering.

The evils existing in all our manufacturing states are thus stated by the Massachusetts committee ("Report of the Committee on Relations between Employer and Employee," pp. $38,39)$ :

"A much greater proportion of personal injury cases than ever before, in comparison with other cases, occupies the attention of trial courts. These cases, good and bad, encumber the court dockets, and in various ways delay the progress of

* St. Louis Cordage Co. v. Miller, I26 Fed. 495, (Nov., Ig03). See also Glenmont Lumber Co. vs. Roy, 126 Fed. 524. 
justice. . . . It is asserted by employers and those representing them that employees are often induced by unscrupulous persons to bring groundless actions against their employers, to rely upon manufactured evidence, and that the sympathies and prejudices of juries frequently favor the employees. It is further claimed that the injured employee, if after a long time he is successful in recovering damages, receives in the end but a small part of the amount so recovered, owing to the expenses of litigation and unreasonable charges of his lawyer and medical advisers.

"On the other hard, it is urged in behalf of the injured employee that the employer, either himself, or, if insured, through his representative, upon the happening of an accident at once sends agents to the place of accident, for the purpose of investigation and to secure evidence. The names of witnesses, together with their statements, are carefully preserved. The employee has no access to this evidence or the names of witnesses, and must prepare his case in the best way he can. It is also asserted that, as soon as the employee can be reached, he is approached by the claim agent of his employer, or by the claim agent of an employers' liability insurance company, if his employer is insured, and urged to settle his claim for damages for a trifling sum. The employee is told that if he goes to law it will be a long time before he gets anything, and that the lawyers will get the larger share.

"If a settlement is not made and a suit follows, a great waste of time and money results to both parties. The plaintiff may be compelled to pay his lawyer liberally, if he is successful; and the defendant may incur the expenses of claim agents, expert witnesses and lawyers, and also assume other expenses incidental to litigation, in addition to the verdict, if one should be rendered against him."

It may be added that, under the law of the assumption of the risks of obvious defects, and of the negligence of fellowservants, there is a multitude of cases where the workman is the victim, without his intentional fault, of the dangers of modern intricate machinery, and yet has no right of action against his employer, and can only bear his misfortune in silence.

The general dissatisfaction with the present state of the law has led to propositions, in almost every legislature, for the enactment of remedial statutes, generally drawn for the purpose of increasing the employer's liability. The abolition of the fellow-servant rule, or of the doctrine that the servant assumes the risks of obvious defects, has been a frequent object in such proposals for legislation.

Even the courts, while adhering to the fellow-servant rule as the existing law, have assisted in the agitation for its alteration. 
Thus the Supreme Court of Errors of Connecticut in 1885 declared (Zeigler v. Danbury \&'c. R. Co., 52 Conn. 556): "The defense of common employment has little of reason or principle to support it, and the tendency in nearly all jurisdictions is to limit rather than enlarge its scope. It must be conceded that it cannot rest on reasons drawn from considerations of justice or of public policy. So far as the rule is to be retained it must have its foundation in the contract theory."

It may perhaps be said with regard to this that to impute to the workman, by mere implication of law, a contract which he did not in fact make, and which cannot be supported by considerations of justice or of public policy, would seem to be a very extreme application of "the contract theory."

Judge Hamersley of the same court, in a note to yo Conn. 194, still more emphatically condemns the fellow-servant rule, and says: "The evil is too deep-seated to be remedied by judicial action; it needs radical treatment through wise legislation."

Such radical treatment has now been given to it by the British Parliament, and is recommended by the Massachusetts committee. They propose, not to amend some details of the existing law of the employer's liability, but to discard it entirely, and to establish the rule of law on a wholly new theoretical basis.

Compensation to the employee for injuries received by him is no longer to rest on the imputation of fault, negligence or other, to the employer. The occurrence of injuries is treated, rather, as an inevitable incident of modern industrial activity, the cost of which should be borne by the business, and be paid for by the consumer in the cost of the article. Every extensive factory must each year spend a considerable sum in the repair and replacement of machinery; but the business involves not only the breaking of machinery, but also the maiming and killing of men. Why is not the latter as much an expense of the business, which should be borne by it, and charged into the price of the product, as the former? Why should the manufacture be carried on so as to be beneficial to the general public and profitable to the proprietor, but to cast a heavy weight of loss upon a few individuals the least able to bear it?

These questions are answered in the proposed "Employees' Compensation Act" by the concise provision in the first clause: "If an employee in any employment to which this act applies receives personal injury while performing duties growing out 
of or incidental to such employment, he shall be paid compensation by the employer in accordance with the scale and conditions of compensation hereinafter provided."

This removes all questions of the employer's tortious negligence, and also all questions of the employee's contributory negligence, or "implied assumption" of risks. The single exception is made in section 4 of injuries received "by reason of his own wilful or fraudulent misconduct." Except for this the only question is, did the injury occur in the course of the employment?

To obviate the natural opposition of employers actuated by fear of having the cost of manufacture greatly increased by this comprehensive liability, the act provides a scale of compensation which seems small indeed in comparison with the verdicts now sometimes recovered in personal injury cases, but which would probably compare more favorably with the net result which now comes into the hands of the victorious plaintiff after paying all his bills of litigation. The basis of computation is not the very difficult standard of the money value of the life of the deceased, of the pain and suffering undergone by him. or of the grief of his surviving relatives. The effort is rather to make good to those who have suffered it the support of his wages which they have lost, so far as that may be done without too great hardship upon the employer.

In case of fatal injury, his dependents, if any, receive an amount approximately equal to his aggregate wages for three years, "or the sum of one thousand dollars, whichever of these sums is the larger, but not exceeding in any case two thousand dollars." If there are no dependents, only the expenses of sickness and burial are to be paid, not exceeding two hundred dollars.

In case of total or partial disability, the injured man is to be paid a weekly payment, not exceeding fifty per cent of his earnings, nor exceeding ten dollars a week, for the period of his disability, not exceeding four years.

Of course, the proposed act contains careful provisions intended to make clear all questions of difficulty likely to arise. It also contains provisions, deemed by the committee most important to its success, for arbitration of all questions of fact arising under it by arbitrators either agreed upon by the parties or appointed by a judge of the Superior Court. This arbitration is to have the force of a judgment. "Any referee so appointed by a justice of the superior court may, at his dis- 
cretion, submit any question of law arising under this act to any justice of the superior court for his decision; and such decision, or a decision rendered by the arbitrator himself in regard to any question of law shall be conclusive, unless exceptions to the same are taken and filed in the supreme judicial court for final determination" (Sec. 24 of the proposed Massachusetts Act).

It is evidently the hope of the committee that the simplicity of the facts imposing liability, and the definiteness of the rate of compensation, will lead to the settlement of the great majority of claims without litigation, even of the kind provided by the act.

This result does not seem to have been obtained very perfectly in the aperation of the English act, as will be seen hereafter, but that may be largely due to the novelty of the problems involved, and to the excessively cautions provisions with which the English act is guarded, many of which English experience enabled the Massachusetts committee to dispense with. The act proposed for Massachusetts is undoubtedly simpler, and seems likely to afford less opportunity for dispute, than the English act.

Mr. Low's report as to the operation of the English act begins with the statement that "careful inquiry made, by personal interviews, of employers, employees, and officials of the Home Office and Board of Trade, who are charged with the execution of the law, justifies the statement that the Workmen's Compensation Act . . . has given as much satisfaction as can be expected from legislation of that character. . . . The objection of the workingman, so far as he has any objection, is not to the act in principle, but to the fact that it does not go far enough. . . . So far as employers are concerned, there is warrant for saying that they have adjusted themselves to conditions; and the compensation which they are compelled to pay does not bear upon them so heavily as to cut seriously into their profits, or to prove a factor in preventing them from retaining their trade in the face of foreign competition. The cost of compensation, I find, large employers regard in the same way as any other fixed charge incidental to and necessary in carrying on business."

He also quotes the Home Office as saying, in a report made in June, xg02, "the number of appeals on questions of law has diminished considerably-the figures for three years are 54,90 and 61 -and there seems therefore reason to hope that progress 
has been made toward the definite settlement of the legal questions in the interpretation of the act of 1897 . On the other hand, the number of cases brought to the county court-in most of which it must be questions of fact that are at issue-still shows an increase. The figures are $x, 347, x, 55^{2}$ and $x, 918$. But even in view of this increase, the statement must be repeated that the cases which come before the county courts do not represent more than a very small proportion of those in which compensation is paid under the act. A great majority of claims are settled by agreement, and only a small percentage are made the subject of formal arbitration."

It would seem that there can be little question of the evils attending the present state of the law in relation to employers' liability for injuries, nor of the inherent justice of the mode of solution now proposed. Nor would its practicability probably be strenuously questioned, if it were not for the fact, made far more important in the United States by the existence of the forty-five states with their separate legislation, that the manufacturer under the act may be exposed to the competition of manufacturers in other jurisdictions, whose liability remains as at common law. This objection necessarily applies to all legislation for the reform of industrial conditions. It has doubtless been urged in every state where laws have been passed for the restriction of child-labor, the limiting of hours, the providing of safety appliances, or any other reform law involving expense to the employer. In this case it was urged so effectively that the Massachusetts General Court of 1904 took no action on the recommendation of the committee.

It is earnestly to be hoped, at least, that this Massachusetts report and proposed act may have the attention, not only from professed economists and reformers, but from lawyers and legislators, that the personal authority of the committee and the care and intelligence of their report amply warrant.

I ought, perhaps, to add that the report (which I think can be obtained by any applicant from the Secretary of the Commonwealth, Boston) also discusses nearly all the burning ques. tions of the day in regard to the relations between employers and employees, and proposes legislation in regard to several matters besides that here discussed. The entire report furnishes material for the careful consideration of those who are interested in the legislative problems created by recent industrial agitation. 